Review Article

\title{
COVID 19-AN OVERVIEW ON EPIDEMIOLOGY, SYMPTOMS, PREVENTION, MANAGEMENT, TREATMENT AND ROLE OF HEALTH WORKERS
}

\author{
MONISHA BANSAL*, MANPREET KAUR WALIA
}

*Shaheed Udham Singh College of Pharmacy, Tangori 140306, Mohali (SAS Nagar), Punjab, India, USPS, Rayat-Bahra University, Mohali, 140104

Email: monishabansal595@gmail.com

Received: 22 May 2020, Revised and Accepted: 25 Jun 2020

\begin{abstract}
With the first case of a highly infectious virus named Coronavirus in Wuhan, China in December 2019, this deadly virus was declared a pandemic by WHO. COVID-19 was found to be very similar to patients infected with MERS-CoV and SARS-CoV. The virus was transmitted from bats to humans through some unidentified intermediary. Since its introduction in humans, it has infected 118000 people, killing 3583 till last week of May 2020 in India. The reported route of transmission is inhalation or direct contact with the infected surface or patients. This symptomatic disease includes symptoms such as cough, fever, sore throat, fatigue, and in some severe patients, it may cause multiple organ failure, pneumonia, severe or acute respiratory diseases. In some cases people may be asymptomatic till $14 \mathrm{~d}$ of infection. The patients with mild illness are usually isolated and others are prevented with protective measures such as medical mask, hand hygiene. In the present article, the epidemiology, route of transmission, clinical symptoms, prevention, management, treatment and role and responsibility of health workers is overviewed on the basis of published research and review articles and current state of knowledge.
\end{abstract}

\section{Keywords: Coronavirus, COVID 19, SARS-CoV 2, Anti-viral drugs, Symptoms, Prevention}

(C) 2020 The Authors. Published by Innovare Academic Sciences Pvt Ltd. This is an open access article under the CC BY license (http://creativecommons.org/licenses/by/4.0/) DOI: http://dx.doi.org/10.22159/ijap.2020v12i5.38411. Journal homepage: https://innovareacademics.in/journals/index.php/ijap

Speedy peer review was done as the subject of the manuscript was related with pandemic.

\section{INTRODUCTION}

A newly emergent virus SARS-CoV-2 caused respiratory tract infection in Wuhan, China in December, 2019. This was named as coronavirus disease 2019 or COVID 2019. It was declared as novel virus that caused the major pandemic $[1,2]$. Although the first case of SARS-CoV occurred in November, 2002 in china and till that time this virus has infected more than a lakh of people worldwide, killing thousands of them [3]. In 2003, World Health Organization (WHO) issued a global alert regarding such cases in Hong Kong and Vietnam $[4,5]$. In 2012, WHO announced the discovery of new virus, MERSCoV that killed 2 patients in Middle East [1]. According to the reports of The Program for Monitoring Emerging Diseases, since 2012, 300 cases of pneumonia were reported due to unidentified causes in China [6, 7]. As per 2003 reports, during the epidemic in Southern China, it was discovered that very similar virus was found in horseshoe bat, Bat SARS-CoV [6, 8-11]. It was also suggested that SARS can return if conditions for virus in the form of mutation, amplification and transmission fit and it could be a potentially dangerous virus. Coronaviruses are known to have high mutation and recombination rates which allow the virus to cross species barrier and adapt to new host [4]. They cause intestinal and respiratory infection in humans and other animals. SARS-CoV and Bat SARS-CoV are together known as 2b-Coronaviruses. SARS-CoV 2 has found to be originated from bat however; there is no evidence so far that it has its origin from seafood market $[6,12]$. The present review indicates the epidemiology, clinical symptoms, prevention, management, treatment and role of heath care workers in COVID 19.

\section{Genomic structure}

CoVs are largest group of all viruses in Nidovirales order, which include Coronaviridae, Roniviridae, and Arteriviridae families. SARS$\mathrm{CoV}$ is among the 36 coronaviruses of the family Coronaviridae [13]. The Coronaviridae is subdivided into two subfamilies named Coronavirinae and Torovirinae. Furthermore, the subfamily Coronavirinae is divided into four groups, the alpha, beta, gamma and delta coronaviruses. Coronavirinae is known to have the largest (approximately 30 kilobase) identified RNA genomes. Coronaviruses are enveloped, non-segmented positive-sense RNA viruses $[14,15]$. The genome acts as a mRNA for translation of replicase polyprotein through 5'cap structure along with 3 ' poly (A) tail. About $2 / 3^{\text {rd }}$ of the genome is occupied by non-structural protein (20kbs) as compared to structural and accessory protein $(10 \mathrm{kbs})$. The RNA replication and transcription occurs through $5^{\prime}$ end containing a leader sequence and untranslated region (UTR) that contain multiple stem loop structures. The 3'UTR also contains RNA structures required for replication and synthesis of viral RNA [16].

The studies of cryo-electron microscopy and cryo-electron tomography depicted that coronavirus virions are spherical in shape with $125 \mathrm{ym}$ of diameter. The surface of the virion show club-shaped spike-like projections, that give them the appearance of solar corona hence named Corona Virus $[17,18]$. The virion envelop consist nucleocapsid. Coronavirus contain 4 structural proteins. The $\mathrm{S}$ protein $(150 \mathrm{kDa})$ makes up the distinctive spikes like structure on surface of the virus $[19,20]$. It is Class I fusion protein involved in the attachment with the host cell [21,22]. This makes S-protein the main target for neutralizing antibody and antiviral peptides [23-27]. The $\mathrm{M}$ protein $(25-30 \mathrm{kDa})$ is the small protein and the most abundant structural protein in virion [28]. The E protein (08-12 $\mathrm{kDa}$ ) is found in small quantities within virion. The E protein is required for pathogenesis in SARS-CoV [29-31]. The $\mathrm{N}$ protein is present in nucleocapsid and composed of two separate domains, Cterminal domain and $\mathrm{N}$-terminal domain. Both domains are capable of binding RNA but by different mechanisms $[32,33]$. Apart from four types of proteins, a fifth type of structural protein is the hemagglutinin-esterase (HE), is present in a subset of betacoronaviruses and enhance the S-protein mediated cell entry and spread through the mucosa $[34,35]$. The genome also consist of open reading frames (ORFs) out of which ORF1a and ORF1b are involved in encoding with 16 non-structural proteins and 7 of them are predicted to be involved in transcription and replication of largest genome. ORF1b is also the molecular target for the design of clinical diagnostic tests [36-45].

\section{Route of transmission}

The rapid economic growth and urbanization has led to higher demand for animal proteins and moreover, the frequent mixing of various animals in densely populated areas with lack of biosafety measures have resulted in the transmission of virus from animal to humans[6, 46-48]. The consumption of wild animals for animal proteins and direct contact with other host animals is the major 
route of coronavirus transmission. Furthermore, the human to human transmission because of lack of awareness and hospital infection control and lack of control of such infections in public places has facilitated the rapid growth of such kind of virus. SARS$\mathrm{CoV} 2$ usually transmit human to human i.e., between family members including friends, neighbours and relatives who contacted the patients or incubation carriers. It transmits through the respiratory tract by Respiratory secretions, respiratory droplets ( $>5-10 \mu \mathrm{m}$ in diameter) and direct contact [49-57]. An analysis on 75,465 coronavirus cases showed no airborne transmission [58]. As per the March 2020 reports by WHO, the airborne transmission may be possible under certain circumstances of endotracheal intubation, manual ventilation, bronchoscopy, open suctioning etc. Some evidence showed that COVID can lead to intestinal infection and be present in faeces but no such fecal-oral transmission has been reported yet [49]. SARS-CoV has 2-3 d of stability in the environment or on dry surface at room temperature, which is higher as compared to other known virus and 2-4 d of survival in stool [59]. However, source and transmission is still elusive. In February 2020, it was reported by National Health Commission, China that approximately $3.8 \%$ of COVID 19 patients transmitted infection to healthcare workers. As COVID-19 is contagious, it is highly transmissible in humans, especially in children and elderly. The most vulnerable age group of patients is 47-59 y out of which $41.9-45.7 \%$ was females. Wuhan, China being the origin of COVID 19 infected 31.3\% of the patients who travelled to Wuhan and $72.3 \%$ of patients that although had no travel history of Wuhan but contacted the people from Wuhan [57]. WHO reported total 5,197,776 confirmed cases of COVID 19 with 334,675 deaths till last week of May 2020 worldwide. In India, $30 \%$ of elderly people aged above $60 \mathrm{y}$ got infected with COVID- 19 and $5 \%$ above $80 \mathrm{y}$ of age.

\section{Clinical characteristics}

SARS being severe acute respiratory syndrome show mild or uncomplicated illness and approximately $14 \%$ require hospitalization and oxygen support and 5\% required admission to an Intensive Care Unit [60]. Most people who suffered from COVID 19 experienced mild to moderate illness and other symptoms include fever, malaise, cough, and mild flu like symptoms. A study conducted by Prof. Nan-Shan Zhong's team, on 1099 confirmed cases found that most common symptoms of coronavirus included fever, cough, fatigue, headache, sputum production, shortness of breath, sore throat, diarrhea and vomiting [61-64]. Less common symptoms may include dyspnea, anorexia and nasal congestion [65]. The elderly people with underlying diseases such as diabetes, hypertension, cardiovascular diseases, chronic obstructive pulmonary diseases etc. developed rapidly into acute respiratory distress syndrome, coagulation dysfunction and even death [54]. Patients with heart disease showed an increase in ACE2 and possibility of heart attack and severe infection [71]. The laboratory examination reports depicted the normal or decreased white blood cells, lymphocytopenia. The neutrophil count, blood urea, D-dimer, inflammatory factors (interleukins, tumor necrosis factor) and creatinine level showed a significant increase [54, 64, 67]. People rapidly developed multiple organ failure, respiratory failure, shock, arrhythmia, acute heart injury, acute respiratory distress syndrome and even deaths [54]. As with elderly, children also get easily infected with the virus because of immature or weak immune system. Therefore, the necessary care and attention is always needed for both age groups [68].

\section{Prevention in case of COVID 19}

- A healthy person should maintain $1 \mathrm{~m}$ away from the infective person or who has respiratory symptoms such as sneezing, coughing.

\section{- Washing hands frequently}

- Sanitizing hands with alcohol-based hand rub when dirt is not visible

- Wearing a medical mask to limit the spread of certain respiratory diseases

- Avoiding over-crowded places, group of people and enclosed spaces
- Covering nose and mouth with an elbow while coughing and sneezing

- Disposing the mask or tissue immediately after use

- Appropriate ventilation/air flow in the living space of patient by opening windows and doors as much as possible

- Replacing mask with a newer one, as soon as it becomes damp

- Discarding used mask and disposing immediately upon removal

- Maintaining a balanced diet, keeping yourself hydrated, exercising regularly and sleeping well $[69,70]$

\section{Management in case of COVID 19}

People with mild illness and no risk factors can be:

- Isolated in non-traditional facilities such as hotels, stadiums, gymnasiums where they can remain till recovery or till laboratory test for COVID 19 are negative

- Isolated in a well-ventilated single room

- The movement should be limited in the house

- Patient's family members should stay in different rooms

- Number of caregivers should be limited and if possible only a person with good health should be assigned

- Relatives or other visitors should not be allowed to enter

- Hand hygiene should be performed

- Surfaces should be cleaned frequently using disinfectants containing $0.1 \%$ sodium hypochlorite

- Clean the clothes, towels of the patients daily with regular detergent and water or machine wash at $60-90{ }^{\circ} \mathrm{C}$ and dry thoroughly

- Mask and other medical waste should be disposed of properly at a sanitary landfill

- Surfaces touched or came in contact with infected patients or with their respiratory secretion or other body fluids should be disinfected with regular disinfectants containing a $0.5 \%$ diluted bleach solution [71]

\section{Myth busters in corona virus}

With the rise in the cases of the Corona virus, the myths related to treatment and spread of diseases also increased. The WHO has advised public to not believe in such myths are given instructions to all worldwide. Following advices were given by WHO:

- No Licensed drug for treatment and prevention of COVID-19: Many reports have shown that hydroxychloroquine has been successful in treatment of Covid 19 but no proof is reported yet. The use of hydroxychloroquine can cause serious side effects and can even lead to death.

- Peppers in soup and other meals do not prevent or cure COVID19: Hot peppers cannot prevent or cure COVID-19. The only way to protect yourself against the disease is Social distancing maintaining atleast $1 \mathrm{~m}$ distance and taking all the precautions.

- Houseflies and Mosquito bites do not transmit Covid 19: COVID 19 spreads only through droplets of an infected person when the patient cough, sneeze or speak. The disease may also spread by touching a contaminated surface and then touching eyes, nose or mouth.

- Spraying, introducing and drinking methanol, ethanol, bleach or another disinfectant will never protect you against COVID-19 and can be dangerous: Use of bleach for spraying on body or drinking is very dangerous and poisonous, it can cause irritation and damage to skin and body.

- Mobile networks (5G) or any Radiowaves do not spread COVID 19. Virus cannot travel through radio waves or mobile networks. 
- Exposing yourself to high temperature or sun does not prevent COVID 19: Even many cases are reported in areas with high temperature or hot weather.

- Holding Breathe for 10 seconds or without cough or feeling discomfort does not mean you are free from disease. The only method to test the disease is laboratory test.

- Alcohol consumption cannot protect you from disease but it would increase the risk of other health problems.

- COVID 19 cannot spread through hot, humid and cold weather.

- Hot bath does not protect from disease

- Ultra-Violet (UV) radiations should not be used to disinfect hands or skin, it only causes skin irritation and damage.

- Eating garlic cannot prevent infection: Although Garlic is a healthy food and it has anti-microbial properties but there is no evidence that it can prevent infection

- Corona virus affect all age groups. Although older age group with existing medical diseases are more vulnerable to disease but all age groups gets affected and all need to stay protected

- Antibiotics are not effective against prevention of COVID 19 [72]

\section{Treatment in case of COVID 19}

\section{Remdesivir}

Remdesivir has been reported to show broad-spectrum antiviral activity against several RNA viruses. Remdesivir is a 1'-cyanosubstituted adenosine nucleotide analog prodrug used to treat the first case of COVID 19 in US successfully. It interferes with the NSP 12 polymerase as studied through in vitro cell line and mouse model $[63,73]$.

\section{Chloroquine}

Chloroquine is an anti-malarial drug that was reported with great potential to treat COVID 19 although, the mechanism against such viral infections was not well understood. Several studies found that chloroquine can interfere with glycosylation of cellular receptors of SAR-CoV. It can inhibit $\mathrm{pH}$-dependent steps of virus replication, an immunomodulatory effect that suppress the production/release of TNF- $\alpha$ and IL-6. It can also interfere with viral infection and replication being novel class of autophagy inhibitor [74-77].

\section{Ribavirin}

Ribavirin is another antiviral drug that was used for the treatment of SARS. It markedly improves symptoms such as fever and improvement in oxygenation and radiographic appearance [78-82]. Although other reports failed to identify the treatment with Ribavirin as most patients received corticosteroids alongwith [83, 84].

\section{IFNs}

Oxygenation and radiographic appearance showed improvement with IFNs specifically IFN-alfacon-1 and high dose of methyl prednisolone that inhibit SARS-CoV in vitro [85-87].

\section{Corticosteroids}

Corticosteroids were found to be effective in SARS therapy and results demonstrated the decrease in virus load. But another report associated with corticosteroid therapy demonstrated that it may worsen the disease. Corticosteroids increase the susceptibility to pathogens, particularly fungal infections [88].

\section{IVIg}

IVIg has been demonstrated to have immunomodulatory properties and downregulate cytokine expression. Convalescent-phase plasma samples containing high levels of anti-SAR CoV antibodies have been used to treat SARS CoV in Hong Kong and China. Plasma exchange was reported as salvage therapy in Hong Kong, but no data of efficacy exist $[89,90]$.
Apart from single and prodrugs, combinational drugs has also shown potential in treatment of COVID 19. In vitro reporys suggested that combination of Remdesivir and Chloroquine was effective in inhibiting SARS-CoV 2. Combination of Lopinavir and Ritonavir (protease inhibitor) was conformed to treat HIV and has potential to improve MERS-CoV and SARS-CoV [91-94]. Korean reports showed that this combination significantly decreased the $\beta$-corona virus viral loads of COVID 19. Another combination of Chinese and western medicines included Lopinavir/Ritonavir, arbidol and Shufeng Jiedu significantly improved the pneumonia symptoms in China [95].

\section{Role and responsibility of health workers}

Health workers should:

- Follow all the protective and preventive measures to minimize occupational health and safety risk

- Follow all the information, training and instructions provided on occupational health and safety risk

- Provide appropriate training on infection prevention control (IPC)

- Provide or ensure that all suspected or confirmed cases of COVID 19 have adequate protective personnel equipment (PPE) such as medical mask, gloves, gowns, sanitizers, soaps and gown etc.

- Provide safety measures to all suspected or confirmed cases of COVID 19

- Self-monitoring the signs and symptoms of COVID 19 and report the illness to managers

- Ensure that workplace and all the surfaces exposed to patients are cleaned and disinfected properly

- Search for the travel history of all the National and International travellers in past few months who came to them with respiratory symptoms

- If the patient is suspected with the disease in OPD they should be provided with masks immediately

- Examiners should use surgical masks and practice hand hygiene frequently

- Suspected cases should be isolated immediately and informed to diagnostic centres of respective state [96-98]

\section{CONCLUSION}

The novel virus outbreak has challenged every country in terms of their economy, medical and public health services. The increased urbanization and people's dependency on animal proteins have the potential that threat of such virus or other deadly infections may likely to continue. Therefore, apart from tackling the current situation globally, the need of the hour is to take comprehensive measures to prevent such outbreak in future.

\section{FUNDING}

Nil

\section{AUTHORS CONTRIBUTIONS}

All the author have contributed equally.

\section{CONFLICT OF INTERESTS}

\section{Declared none}

\section{REFERENCES}

1. Christian MD, Poutanen SM, Loutfy MR, Muller MP, Low DE. Severe acute respiratory syndrome. Clin Infect Dis 2004;38:1420-7.

2. World Health Organization. Summary of probable SARS cases with onset of illness from 1 November 2002 to 31 July 2003. Available from: https://www.who.int/csr/sars/country/ table2004_04_21/en/. [Last accessed on 04 Apr 2020]. 
3. Biosafety and SARS incident in Singapore September: Report of the Review Panel on New SARS Case and Biosafety. World Health Organization. Singapore Ministry of Health; 2003.

4. Lau SK, Chan JF. Coronaviruses: emerging and re-emerging pathogens in humans and animals. Virol J 2015;12:1-3.

5. Zaki AM, Van Boheemen S, Bestebroer TM, Osterhaus AD, Fouchier RA. Isolation of a novel coronavirus from a man with pneumonia in Saudi Arabia. N Engl J Med 2012;367:1814-20.

6. Lau SK, Woo PC, Li KS, Huang Y, Tsoi HW, Wong BH, et al. Severe acute respiratory syndrome coronavirus-like virus in Chinese horseshoe bats. Proc Natl Acad Sci USA 2005;102:14040-5.

7. Ge XY, Li JL, Yang XL, Chmura AA, Zhu G, Epstein JH, et al. Isolation and characterization of a bat SARS-like coronavirus that uses the ACE2 receptor. Nature 2013;503:535-8.

8. Cheng VC, Lau SK, Woo PC, Yuen KY. Severe acute respiratory syndrome coronavirus as an agent of emerging and reemerging infection. Clin Microbiol Rev 2007;20:660-94.

9. Che XY, Di B, Zhao GP, Wang YD, Qiu LW, Hao W, et al. A patient with asymptomatic severe acute respiratory syndrome (SARS) and antigenemia from the 2003-2004 community outbreak of SARS in Guangzhou, China. Clin Infect Dis 2006;43:e1-e5.

10. Li W, Shi Z, Yu M, Ren W, Smith C, Epstein JH, et al. Bats are natural reservoirs of SARS-like coronaviruses. Science 2005;310:676-9.

11. Wang M, Yan M, Xu H, Liang W, Kan B, Zheng B, et al. SARS-CoV infection in a restaurant from palm civet. Emerg Infect Dis 2005;11:1860-5.

12. Ren W, Li W, Yu M, Hao P, Zhang Y, Zhou P, et al. Full-length genome sequences of two SARS-like coronaviruses in horseshoe bats and genetic variation analysis. J Gen Virol 2006;87:3355-9.

13. Marra MA, Jones SJ, Astell CR, Holt RA, Brooks Wilson A, Butterfield YS, et al. The genome sequence of the SARSassociated coronavirus. Science 2003;300:1399-404.

14. Kanaan Al-Tameemik, Kabakli R. Novel coronavirus (2019nCoV): disease briefings. Asian J Pharm Clin Res 2020;13:22-7.

15. Majumdar A, Malviya N, Alok S. An overview on covid-19 outbreak: epidemic to pandemic. Int J Pharm Sci Res 2020;11:1958-68.

16. Fehr AR, Perlman S. Coronaviruses: an overview of their replication and pathogenesis. Methods Mol Biol 2015;1282:123.

17. Barcena M, Oostergetel GT, Bartelink W, Faas FG, Verkleij A, Rottier PJ, et al. Cryo-electron tomography of mouse hepatitis virus: Insights into the structure of the coronavirion. Proc Natl Acad Sci USA 2009;106:582-7.

18. Neuman BW, Adair BD, Yoshioka C, Quispe JD, Orca G, Kuhn P, et al. Supramolecular architecture of severe acute respiratory syndrome coronavirus revealed by electron cryomicroscopy. J Virol 2006;80:7918-28.

19. Beniac DR, Andonov A, Grudeski E, Booth TF. Architecture of the SARS coronavirus prefusion spike. Nat Struct Biol 2006;13:751-2.

20. Delmas B, Laude H. Assembly of coronavirus spike protein into trimers and its role in epitope expression. J Virol 1990;64:5367-75

21. Bosch BJ, van der Zee R, de Haan CA, Rottier PJ. The coronavirus spike protein is a class I virus fusion protein: structural and functional characterization of the fusion core complex. J Virol 2003;77:8801-11.

22. Collins AR, Knobler RL, Powell H, Buchmeier MJ. Monoclonal antibodies to murine hepatitis virus-4 (strain JHM) define the viral glycoprotein responsible for attachment and cell-cell fusion. Virol 1982;119:358-71.

23. Ingallinella $\mathrm{P}$, Bianchi $\mathrm{E}$, Finotto $\mathrm{M}$, Cantoni $\mathrm{G}$, Eckert $\mathrm{DM}$, Supekar VM, et al. Structural characterization of the fusionactive complex of severe acute respiratory syndrome (SARS) coronavirus. Proc Natl Acad Sci USA 2004;101:8709-14.

24. Li F, Li W, Farzan M, Harrison SC. Structure of SARS coronavirus spike receptor-binding domain complexed with receptor. Science 2005;309:1864-8.

25. Liu S, Xiao G, Chen Y, He Y, Niu J, Escalante CR, et al. Interaction between heptad repeat 1 and 2 regions in spike protein of
SARS-associated coronavirus: implications for virus fusogenic mechanism and identification of fusion inhibitors. Lancet 2004;363:938-47.

26. Simmons G, Reeves JD, Rennekamp AJ, Amberg SM, Piefer AJ, Bates P. Characterization of severe acute respiratory syndrome associated coronavirus (SARS-CoV) spike glycoproteinmediated viral entry. Proc Natl Acad Sci USA 2004;101:4240-5.

27. Tripet B, Howard MW, Jobling M, Holmes RK, Holmes KV, Hodges RS. Structural characterization of the SARS-coronavirus spike S fusion protein core. J Biol Chem 2004;279:20836-49.

28. Armstrong J, Niemann H, Smeekens S, Rottier P, Warren G. Sequence and topology of a model intracellular membrane protein, E1 glycoprotein, from a coronavirus. Nature 1984;308:751-2.

29. Godet M, L'Haridon R, Vautherot JF, Laude H. TGEV corona virus ORF4 encodes a membrane protein that is incorporated into virions. Virology 1992;188:666-75.

30. DeDiego ML, Alvarez E, Almazan F, Rejas MT, Lamirande E, Roberts A, et al. A severe acute respiratory syndrome coronavirus that lacks the E gene is attenuated in vitro and in vivo. J Virol 2007;81:1701-13.

31. Nieto Torres JL, Dediego ML, Verdia Baguena C, Jimenez Guardeno JM, Regla Nava JA, Fernandez Delgado R, et al. Severe acute respiratory syndrome coronavirus envelope protein ion channel activity promotes virus fitness and pathogenesis. PLoS Pathogens 2014;10:1004077.

32. Chang CK, Sue SC, Yu TH, Hsieh CM, Tsai CK, Chiang YC, et al. Modular organization of SARS coronavirus nucleocapsid protein. J Biomed Sci 2006;13:59-72.

33. Hurst KR, Koetzner CA, Masters PS. Identification of in vivointeracting domains of the murine coronavirus nucleocapsid protein. J Virol 2009;83:7221-34.

34. Klausegger A, Strobl B, Regl G, Kaser A, Luytjes W, Vlasak R. Identification of a coronavirus hemagglutinin-esterase with a substrate specificity different from those of influenza C virus and bovine coronavirus. J Virol 1999;73:3737-43.

35. Cornelissen LA, Wierda CM, Van der Meer FJ, Herrewegh AA, Horzinek MC, Egberink HF, et al. Hemagglutinin-esterase, a novel structural protein of torovirus. J Virol 1997;71:5277-86.

36. Egloff MP, Ferron F, Campanacci V, Longhi S, Rancurel C, Dutartre $\mathrm{H}$, et al. The severe acute respiratory syndromecoronavirus replicative protein nsp9 is a single-stranded RNAbinding subunit unique in the RNA virus world. Proc Natl Acad Sci USA 2004;101:3792-6.

37. Fan Z, Peng K, Tan X, Yin B, Dong X, Qiu F, et al. Molecular cloning, expression, and purification of SARS-CoV nsp13. Protein Expr Purif 2005;41:235-40.

38. Imbert I, Guillemot JC, Bourhis JM, Bussetta C, Coutard B, Egloff $\mathrm{MP}$, et al. A second, non-canonical RNA-dependent RNA polymerase in SARS coronavirus. Embo J 2006;25:4933-42.

39. Joseph JS, Saikatendu KS, Subramanian V, Neuman BW, Brooun A, Griffith M, et al. Crystal structure of nonstructural protein 10 from the severe acute respiratory syndrome coronavirus reveals a novel fold with two zinc-binding motifs. J Virol 2006;80:7894-901.

40. Minskaia E, Hertzig T, Gorbalenya AE, Campanacci V, Cambillau C, Canard B, et al. Discovery of an RNA virus 335 exoribonuclease that is critically involved in coronavirus RNA synthesis. Proc Natl Acad Sci USA 2006;103:5108-13.

41. Ricagno S, Egloff MP, Ulferts R, Coutard B, Nurizzo D, Campanacci V, et al. Crystal structure and mechanistic determinants of SARS coronavirus nonstructural protein 15 define an endoribonuclease family. Proc Natl Acad Sci USA 2006;103:11892-7.

42. Su D, Lou Z, Sun F, Zhai Y, Yang H, Zhang R, et al. Do-decamer structure of severe acute respiratory syndrome coronavirus nonstructural protein nsp10. J Virol 2006;80:7902-8.

43. Sutton G, Fry E, Carter L, Sainsbury S, Walter T, Nettleship J, et al. The nsp9 replicase protein of SARS-coronavirus, structure and functional insights. Structure 2004;12:341-53.

44. Von Grotthuss M, Wyrwicz LS, Rychlewski L. mRNA cap-1 methyltransferase in the SARS genome. Cell 2003;113:701-2.

45. Zhai Y, Sun F, Li X, Pang H, Xu X, Bartlam M, et al. Insights into SARS-CoV transcription and replication from the structure of 
the nsp7-nsp8 hexadecamer. Nat Struct Mol Biol 2005;12:9806.

46. Ge XY, Li JL, Yang XL, Chmura AA, Zhu G, Epstein JH, et al. Isolation and characterization of a bat SARS-like coronavirus that uses the ACE2 receptor. Nature 2013;503:535-8.

47. Webster RG. Wet markets-a continuing source of severe acute respiratory syndrome and influenza. Lancet 2004;363:234-6.

48. Woo PC, Lau SK, Yuen KY. Infectious diseases emerging from Chinese wet-markets: zoonotic origins of severe respiratory viral infections. Curr Opin Infect Dis 2006;19:401-7.

49. World Health Organization. Modes of transmission of virus causing COVID-19: implications for IPC precaution recommendations. Scientific Brief 2020.

50. Infection prevention and control of epidemic-and pandemicprone acute respiratory infections in health care. World Health Organization; 2014.

51. Liu J, Liao X, Qian S, Yuan J, Wang F, Liu Y, et al. Community transmission of severe acute respiratory syndrome coronavirus 2, Shenzhen, China, 2020. Emerg Infect Dis 2020;26. DOI:10.3201/eid2606.200239.

52. Chan W, Yuan S, Hang Kok K, Kai-Wang K, Chu H, Yang J, et al. A familial cluster of pneumonia associated with the 2019 novel coronavirus indicating person-to-person transmission: a study of a family cluster. Lancet 2020;395:P514-523.

53. Li Q, Guan X, Wu P, Wang X, Zhou L, Tong Y, et al. Early transmission dynamics in Wuhan, China, of novel coronavirusinfected pneumonia. N Engl J Med 2020;382:1199-207.

54. Huang C, Wang Y, Li X, Zhao J, Hu Y. Clinical features of patients infected with 2019 novel coronavirus in Wuhan, China. Lancet 2020;395:497-506.

55. Burke RM, Midgley CM, Dratch A, Fenstersheib M, Haupt T, Holshue $\mathrm{M}$, et al. Active monitoring of persons exposed to patients with confirmed covid-19-United States, JanuaryFebruary 2020. MMWR Morb Mortal Wkly Rep 202 0;69:245-6.

56. Report of the WHO-China Joint Mission on Coronavirus Disease 2019 (COVID-19) 16-24 February 2020. World Health Organization; 2020.

57. Guo $\mathrm{Y}$, Cao $\mathrm{Q}$, Hong $\mathrm{Z}$, Tan $\mathrm{Y}$, Chen $\mathrm{S}$, Jin $\mathrm{H}$, et al. The origin, transmission and clinical therapies on coronavirus disease 2019 (covid-19) outbreak-an update on the status. Mil Med Res 2020;7:1-10.

58. Ong SW, Tan YK, Chia PY, Lee TH, Ng OT, Wong MS, et al. Air, surface environmental, and personal protective equipment contamination by severe acute respiratory syndrome coronavirus 2 (SARS-CoV-2) from asymptomatic patient. JAMA. 2020.

59. Rabenau HF, Cinatl J, Morgenstern B, Bauer G, Preiser W, Doerr HW. Stability and inactivation of SARS coronavirus. Med Microbiol Immunol 2005;194:1-6.

60. Vital surveillances: the epidemiological characteristics of an outbreak of 2019 novel coronavirus diseases (Covid-19)-China. China CDC Weekly 2020;2:113-22.

61. Madjid M, Safavi Naeini P, Solomon S, Vardeny O. Potential effects of coronaviruses on the cardiovascular system. A Review, JAMA Cardiol 2020;1286:E1-E10.

62. Yeo C, Kaushal S, Yeo D. Enteric involvement of coronaviruses: is the faecal-oral transmission of SARS-CoV 2 possible? Lancet Gastroenterol Hepatol 2020;5:335-7.

63. Holshue ML, DeBolt C, Lindquist S, Lofy KH, Wiesman J, Bruce $\mathrm{H}$, et al. First case of 2019 novel coronavirus in the United States. N Engl J Med 2020;382:929-36.

64. Guan WJ, Ni ZY, Hu Y, Liang WH, Ou CQ, He JX, et al. Clinical characteristics of coronavirus disease 2019 in China. N Engl J Med 2020.

65. Coronavirus disease 2019 (COVID-19). Centres for Disease Control and Prevention; 2020.

66. Chen L, Li X, Chen M, Feng Y, Xiong C. The ACE2 expression in human heart indicates new potential mechanism of heart injury among patients infected with SARS-CoV-2. Cardiovas Res 2020. DOI:10.1093/cvr/cvaa078

67. Kui L, Fang YY, Deng Y, Liu W, Wang MF, Ma JP, et al. Clinical characteristics of novel coronavirus cases in tertiary hospitals in Hubei Province. Chin Med J 2020;133:1025-31.

68. Wang J, Qi H, Bao L, Li F, Shi Y. A contingency plan for the management of the 2019 novel coronavirus outbreak in neonatal intensive care units. Lancet Child Adolesc Health 2020;4:258-9.

69. World Health Organization. Infection prevention and control during health care when COVID-19 is suspected: Interim guidance. World Health Organization; 2020.

70. World Health Organization. Advice on the use of masks in the community, during home care, and in health care settings in the context of covid-19: interim guidance; 2020.

71. World Health Organization. Home care for patients with covid19 presenting with mild symptoms and management of their contacts: interim guidance. World Health Organization; 2020.

72. Coronavirus disease (Covid-19) advice for the public: myth busters. World Health Organization; 2020.

73. Agostini ML, Andres EL, Sims AC, Graham RL, Sheahan TP, Lu X, et al. Coronavirus susceptibility to the antiviral remdesivir (gs5734) is mediated by the viral polymerase and the proofreading exoribonuclease. mBio 2018;9:e0221-18.

74. Aguiar A, Murce E, Cortopassi W, Pimentel A, Almeida M, Barros D, et al. Chloroquine analogs as antimalarial candidates with potent in vitro and in vivo activity. Int J Parasitol Drugs Drug Resist 2018;8:459-64.

75. Savarino A, Boelaert J, Cassone A, Majori G, Cauda R. Effects of chloroquine on viral infections: an old drug against today's diseases. Lancet Infect Dis 2003;3:722-7.

76. Vincent MJ, Bergeron E, Benjannet S, Erickson BR, Rollin PE, Ksiazek TG, et al. Chloroquine is a potent inhibitor of SARS coronavirus infection and spread. Virol J 2005;2:69.

77. Golden EB, Cho HY, Hofman FM, Louie SG, Schonthal AH, Chen TC. Quinoline-based antimalarial drugs: a novel class of autophagy inhibitors. Neurosurg Focus 2015;38:E12.

78. Arabi YM, Shalhoub S, Mandourah Y, Al-Hameed F, Al-Omari A, $\mathrm{Al}$ Qasim E, et al. Ribavirin and interferon therapy for critically ill patients with middle east respiratory syndrome: a multicenter observational study. Clin Infect Dis 2019;70:183744.

79. Poutanen SM, Low DE, Henry B, Finkelstein S, Rose D, Green K, et al. Identification of severe acute respiratory syndrome in Canada. N Engl J Med 2003;348:1995-2005.

80. Lee N, Hui D, Wu A, Chan P, Cameron P, Joynt GM, et al. A major outbreak of severe acute respiratory syndrome in Hong Kong. N Engl J Med 2003;348:1986-94.

81. Koren G, King S, Knowles S, Phillips E. Ribavirin in the treatment of SARS: a new trick for an old drug? CMAJ 2003;168:1289-92.

82. Tsang KW, Ho PL, Ooi GC, Yee WK, Wang T, Chan Yeung M, et al. A cluster of cases of severe acute respiratory syndrome in Hong Kong. N Engl J Med 2003;348:1977-85.

83. Hsu LY, Lee CC, Green JA, Ang B, Paton NI, Lee L, et al. Severe acute respiratory syndrome (SARS) in singapore: clinical features of index patient and initial contacts. Emerg Infect Dis 2003;9:713-7.

84. Booth CM, Matukas LM, Tomlinson GA, Rachlis AR, Rose DB, Dwosh HA, et al. Clinical features and short-term outcomes of 144 patients with SARS in the greater toronto area. JAMA 2003;289:2801-9.

85. Samuel CE. Antiviral actions of interferons. Clin Microbiol Rev 2001;14:778-809.

86. Cinatl J, Morgenstern B, Bauer G, Chandra P, Rabenau H, Doerr HW. Treatment of SARS with human interferons. Lancet 2003;362:293-4.

87. Loutfy M, Blatt L, Ward S, Ward S, Wolff B, Lho $\mathrm{H}$, et al. Interferon alfacon-1 plus corticosteroids in severe acute respiratory syndrome: a preliminary study. JAMA 2003;290:3222-8.

88. Zhao Z, Zhang $\mathrm{F}, \mathrm{Xu} \mathrm{M}$, Huang $\mathrm{K}$, Zhong $\mathrm{W}$, Cai $\mathrm{W}$, et al. Description and clinical treatment of an early outbreak of severe acute respiratory syndrome (SARS) in Guangzhou, PR China. J Med Microbiol 2003;52:715-20.

89. Peiris J, Chu C, Cheng V, Chan KS, Hung IF, Poon LL, et al. Clinical progression and viral load in a community outbreak of coronavirus-associated SARS pneumonia: a prospective study. Lancet 2003;361:1767-72.

90. Tsang K, Zhong NS. SARS: pharmacotherapy. Respirol 2003;8:S25-30. 
91. Arabi YM, Asiri AY, Assiri AM, Aziz Jokhdar HA, Alothman A, Balkhy HH, et al. Treatment of Middle East respiratory syndrome with a combination of lopinavir/ritonavir and interferon- $\beta 1 \mathrm{~b}$ (MIRACLE trial): statistical analysis plan for a recursive two-stage group sequential randomized controlled trial. Trials 2020;21:8.

92. Chu CM, Cheng VC, Hung IF, Wong MM, Chan KH, Chan KS, et al. Role of lopinavir/ritonavir in the treatment of SARS: initial virological and clinical findings. Thorax 2004;59:252-6.

93. Lim J, Jeon S, Shin HY, Kim MJ, Seong YM, Lee WJ, et al. Case of the index patient who caused tertiary transmission of covid-19 infection in Korea: the application of lopinavir/ritonavir for the treatment of covid-19 infected pneumonia monitored by quantitative RT-PCR. J Korean Med Sci 2020;35:e79.

94. Wang Z, Chen X, Lu Y, Chen F, Zhang W. Clinical characteristics and therapeutic procedure for four cases with 2019 novel coronavirus pneumonia receiving combined Chinese and Western medicine treatment. Biosci Trends 2020;14:64-8.

95. Chan KS, Lai ST, Chu CM, Tsui E, Tam CY, Wong MM, et al. Treatment of severe acute respiratory syndrome with lopinavir/ritonavir: a multicentre retrospective matched cohort study. Hong Kong Med J 2003;9:399-406.

96. World Health Organization. Coronavirus disease (covid-19) outbreak: rights, roles and responsibilities of health workers, including key considerations for occupational safety and health: Interim guidance. World Health Organization; 2020.

97. Singhal T. A review of coronavirus disease-2019 (covid-19). Indian J Pediatr 2020;87:281-6.

98. Choudhury J, Mahapatra A. Knowledge of hand hygiene practices among health-care workers in neonatal and pediatric intensive care unit of a tertiary care hospital of odisha. Asian J Pharm Clin Res 2017;10:272-4. 